\title{
A case series of flow-through free anterolateral thigh flap to augment the vascularity of ischaemic limbs with soft tissue defect
}

\author{
Aditya Aggarwal, Hardeep Singh, Sanjay Mahendru, Vimalendu Brajesh, Sukhdeep Singh, \\ Srinivasan Krishnan, Rakesh Kumar Khazanchi \\ Department of Plastic Reconstructive and Aesthetic Surgery, Medanta - The Medicity, Gurgaon, Haryana, India
}

Address for correspondence: Dr. Aditya Aggarwal, Department of Plastic Reconstructive and Aesthetic Surgery, Medanta - The Medicity, Sector 38, NCR, Gurgaon - 122 001, Haryana, India. E-mail: aditya_agg@hotmail.com

\section{ABSTRACT}

Introduction: In a world of fast moving vehicles, heavy machinery and industries crush injury to limbs with vascular compromise and soft tissue defect is common. The traditional treatment is a 2 step one dealing with vascular repair and soft tissue cover separately, in the same operation. We report a series of single step vascular repair and soft tissue cover with flow through anterolateral thigh flap (ALT) flap for limb salvage. Materials and Methods: Ten patients with soft tissue defect and vascular injury were included in this study. A two team approach was used to minimise operative time, team one prepared the vessels and team 2 harvested the flap. Observations and Results: Of the ten patients operated (8 males), eight flaps were done for upper limb and two for lower limb salvage. Six anastomosis were done with ulnar vessels, two with radial and two with posterior tibial vessels. Nine extremities could be salvaged while one patient developed progressive thrombosis leading to amputation. Conclusion: The ALT flow-through flap is a versatile single step procedure that can be used to salvage an ischemic limb with soft tissue loss avoiding the need for interpositional vein graft.

\section{KEY WORDS}

Flow through flap; vascular compromise; Salvage

\section{INTRODUCTION}

$\mathrm{n}$ a world of fast moving vehicles, heavy machinery industries, warfare injuries and bomb blasts the incidence of crush injury to limbs is fast increasing. Skin and soft tissue loss when not associated with vascular injury warrants a simple reconstruction, but the

\begin{tabular}{|l|l|}
\hline \multicolumn{2}{|c|}{ Access this article online } \\
\hline Quick Response Code: & Website: \\
\hline & www.ijps.org \\
\cline { 2 - 2 } & DoI: \\
\hline
\end{tabular}

presence of concurrent vascular injury [Diagram 1] makes reconstruction complex. Traditionally, treatment involves the repair of vascular injury by a reversed vein graft followed by soft tissue reconstruction using pedicled or free flaps [Diagram 2]. However, if the simultaneous skin and soft tissue reconstruction is being planned free tissue transfer

This is an open access article distributed under the terms of the Creative Commons Attribution-NonCommercial-ShareAlike 3.0 License, which allows others to remix, tweak, and build upon the work non-commercially, as long as the author is credited and the new creations are licensed under the identical terms.

For reprints contact: reprints@medknow.com

How to cite this article: Aggarwal A, Singh $\mathrm{H}$, Mahendru $\mathrm{S}$, Brajesh V, Singh S, Krishnan S, et al. A case series of flow-through free anterolateral thigh flap to augment the vascularity of ischaemic limbs with soft tissue defect. Indian J Plast Surg 2016;49:35-41. 
with flow through anastomosis [Diagram 3] is a valuable option. Soutar et al. first suggested the flow-through principle for intra-oral reconstruction. In flow through flaps soft tissue coverage and distal revascularisation is achieved. Several flaps have been described taking advantage of the flow-through principle, such as the radial forearm, ${ }^{[1,2]}$ scapular $^{[3]}$ and peroneal ${ }^{[3]}$ flaps. The anterolateral thigh flap (ALT), a perforator flap first described by Song et al. has the advantage of a large pedicle of $2-3 \mathrm{~mm}$ diameter, a long pedicle, a large skin island ${ }^{[4,5]}$ and it leaves an inconspicuous donor scar with minimal donor-site morbidity. ${ }^{[6,7]}$ There have been isolated reports of ALT flow through flap being used for salvage of limbs along with soft tissue coverage. We report here a series of 10 cases in which ALT flow through flaps were used for augmenting the vascularity of the limbs.

\section{MATERIALS AND METHODS}

In a prospective study in Department of Plastic, aesthetic and reconstructive surgery from 1 January 2013 to

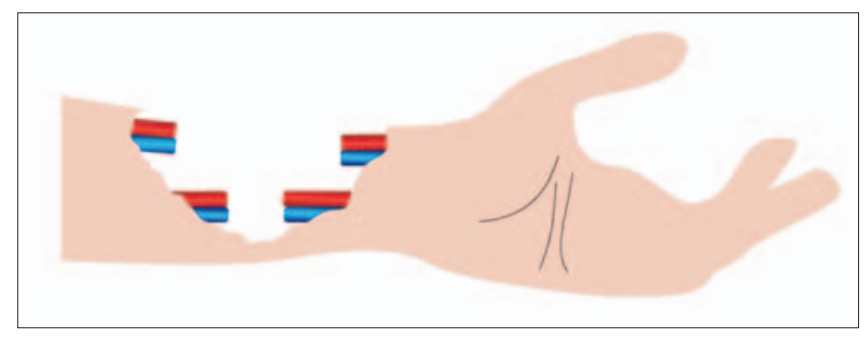

Diagram 1: Soft tissue injury to limb with ischemia

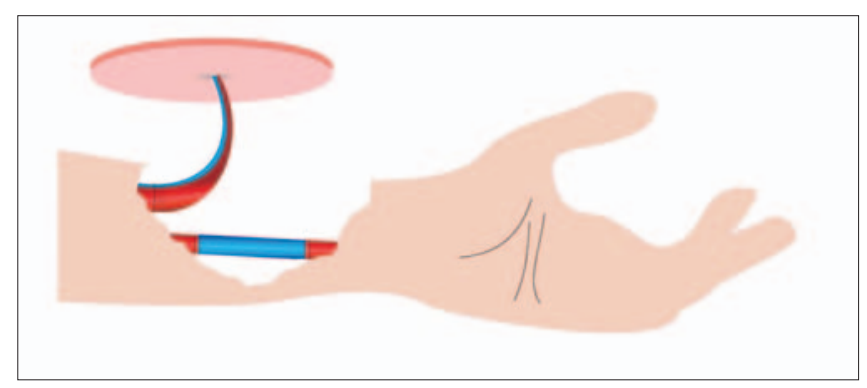

Diagram 2: Reverse vein graft for vascularity and flap cover to soft tissue defect

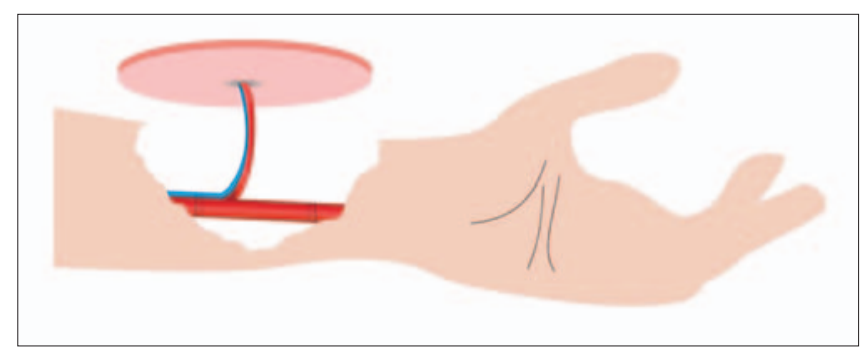

Diagram 3: Simultaneous coverage and restoration of vascularity of limb by flow through flap
31 December 2014, ten patients with crush injury to upper and lower extremities with vascular compromise were assessed. Reconstruction was done for ten patients; eight patients with upper limb and 2 for lower limb ischemia.

The procedure involves a two team approach. The first team conducts the debridement, repairs the injured structures and prepares the recipient vessels. The second team harvests the ALT flow through the flap. Once the size of the skin paddle and length of flow through segment required is finalized the flap is maximized on the descending branch of the lateral circumflex femoral artery (LCFA) and its adequate length preserved distal to the take-off of the skin perforator. The flap is transferred in the defect and temporarily stapled. Arterial anastomosis is first done proximally and then distally to revascularise the distal extremity taking advantage of the distal runoff of the descending LCFA. After confirming the vascular flow in the distal extremity the venous anastomosis is done and a final flap insetting is done over drains. Low molecular weight heparin 2500 IU subcutaneously is given once intraoperatively and continued as a single daily dose for the $1^{\text {st }}$ post-operative week. Ecosprin $75 \mathrm{mg}$ is given once daily for a month. The patient is hydrated and monitored carefully maintaining a urine output of at least $1 \mathrm{ml} / \mathrm{kg} / \mathrm{h}$. Limb elevation is continued for 2 weeks and dressings are changed every $3^{\text {rd }}$ day.

\section{OBSERVATIONS AND RESULTS}

Out of ten patients (eight males), a flow through flap was done in eight patients with upper limb and 2 cases of lower limb ischaemia [Table 1]. Flow through was done with ulnar vessels in 6 cases, radial vessels in 2 cases and posterior tibial vessels for 2 cases. The age of the patients ranged from 13 years to 55 years. The size of the skin paddle varied from $5 \mathrm{~cm} \times 6 \mathrm{~cm}$ to $19 \mathrm{~cm} \times 10 \mathrm{~cm}$. The length of the flow through a segment of descending branch of circumflex femoral vessels varied from $8 \mathrm{~cm}$ to $14 \mathrm{~cm}$ [Table 2]. Donor area of the flap was closed primarily in seven patients, and the rest were grafted.

Table 1: Demographic profile

\begin{tabular}{lccccccc} 
Type of & \multicolumn{4}{c}{ Age } & & & \multicolumn{3}{c}{ Gender } \\
\cline { 2 - 4 } \cline { 6 - 8 } surgery & Mean & SD & Range & & Male & Female & Total \\
\hline Posttibial & 39.50 & 21.920 & $24-55$ & & 2 & 0 & 2 \\
Radial & 21.50 & 12.021 & $13-30$ & & 2 & 0 & 2 \\
Ulnar & 24.83 & 3.920 & $18-30$ & & 4 & 2 & 6 \\
Total & 27.10 & 11.070 & $13-55$ & & 8 & 2 & 10 \\
\hline SD: Standard deviation & & & & &
\end{tabular}


Table 2: Size of skin and length of flow

\begin{tabular}{|c|c|c|c|c|c|c|c|c|c|}
\hline \multirow[t]{2}{*}{ Type of surgery } & \multicolumn{2}{|c|}{ Part revascularized } & \multirow[t]{2}{*}{ Total } & \multicolumn{3}{|c|}{ Size of skin paddle $\left(\mathrm{cm}^{2}\right)$} & \multicolumn{3}{|c|}{$\begin{array}{l}\text { Length of flow through segment } \\
\text { (cm) }\end{array}$} \\
\hline & Foot & Hand & & Mean & $S D$ & Range & Mean & $S D$ & Range \\
\hline Posttibial & 2 & 0 & 2 & 84.00 & 16.971 & $72-96$ & 11.50 & 2.121 & $10-13$ \\
\hline Radial & 0 & 2 & 2 & 67.50 & 10.607 & $60-75$ & 12.00 & 2.828 & $10-14$ \\
\hline Ulnar & 0 & 6 & 6 & 93.67 & 56.472 & $30-190$ & 11.17 & 2.714 & $8-15$ \\
\hline Total & 2 & 6 & 10 & 86.50 & 43.955 & $30-190$ & 11.40 & 2.366 & $8-15$ \\
\hline
\end{tabular}

SD: Standard deviation

The flow through ALT flap survived in all the patients. In 9 out of ten patients, the distal extremity was also salvaged. One patient who came $14 \mathrm{~h}$ after the injury with initial assessment of a doubtful vascularity of hand landed with progressive thrombosis and eventually needed an amputation. The follow-up period of the flaps varies from 6 months to 2 years.

A 18-year-old female patient presented to us with a month old high tension electrical injury to right forearm and hand. The patient was managed in a previous hospital with multiple sessions of debridement and dressings. All the flexor tendons, median and ulnar nerves, the ulnar artery were debrided in previous surgeries. The hand was surviving on the radial artery alone. The patient had blown out of the radial artery $4 \mathrm{~h}$ before presenting to us and it was ligated outside. She presented to us with a devascularised hand [Figure 1]. She was taken up for an emergency flow through flap which was hooked to the ulnar vessels and the hand was salvaged [Figures 2-4]. She required other surgeries for raw areas over the right hand and thumb.

Another patient, a 26-year-old male presented to us with 4 day old mine blast injury to both the lower limbs. Emergency below knee amputation of the left lower limb and debridement of right lower limb with fracture fixation by external fixator was done at the primary care centre [Figure 5]. As the anterial tibial vessels were transected a vascular surgeon in the previous hospital had put a vein graft on the posterior tibial artery. At presentation to us the patient had ischemic pain in the foot and a raw area on the anteromedial aspect of the lower $1 / 3^{\text {rd }}$ of the leg. During surgery, it was found that there was necrotic tissue around the vein graft, and the vein graft was also thrombosed. Adequate debridement and flow through ALT flap [Figures 6 and 7] was done to the posterior tibial vessels to salvage the limb and provide soft tissue cover [Figure 8].

A 13-year-old boy presented to us $5 \mathrm{~h}$ after a railway accident with an amputation at left forearm level and

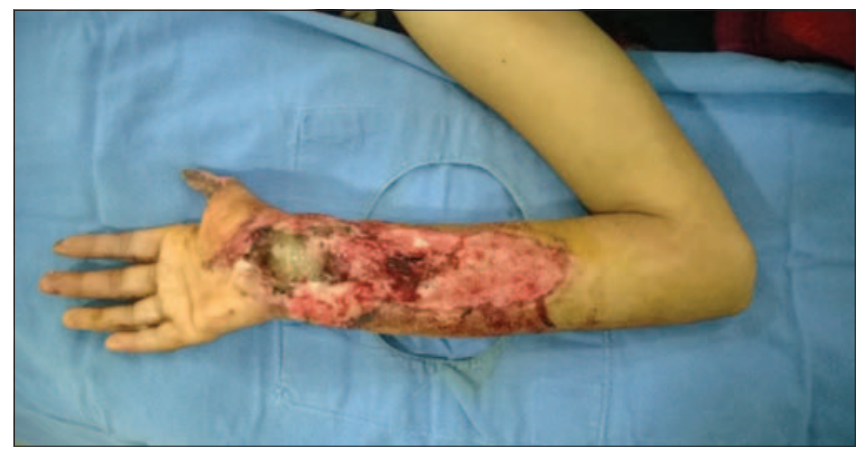

Figure 1: Ischemic hand with soft tissue loss

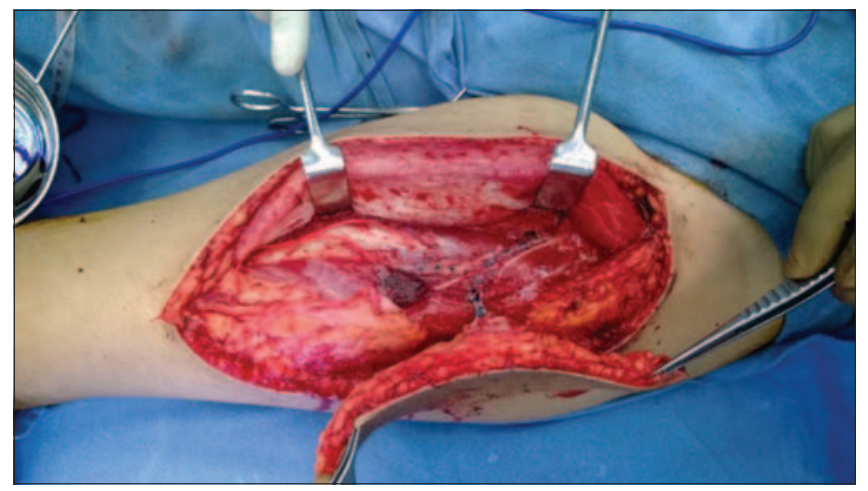

Figure 2: Harvesting of flow through anterolateral thigh flap

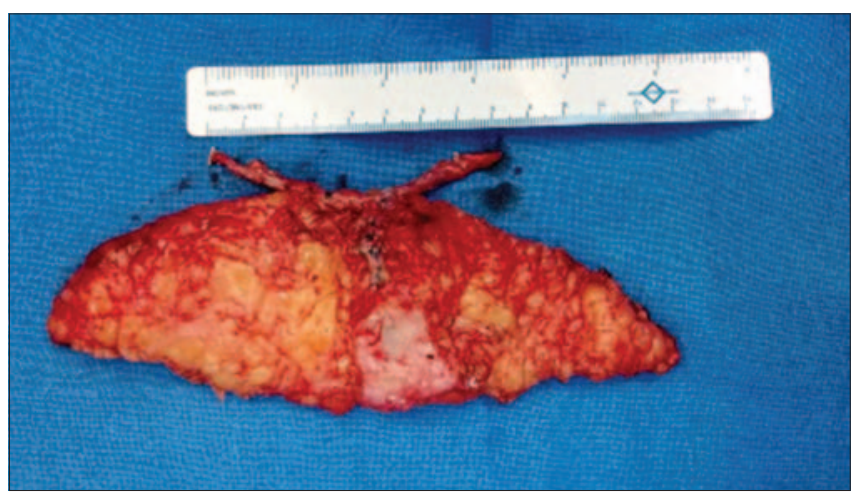

Figure 3: Harvested flow through flap

left lower limb vascular injury [Figures 9 and 10]. He underwent replantation of hand with bone shortening and repair of radial vessels only (as ulnar vessels were avulsed). The patient started developing necrosis of forearm skin and gradual ischaemia of replanted hand [Figure 11].

Indian Journal of Plastic Surgery January-April 2016 Vol 49 Issue 1 


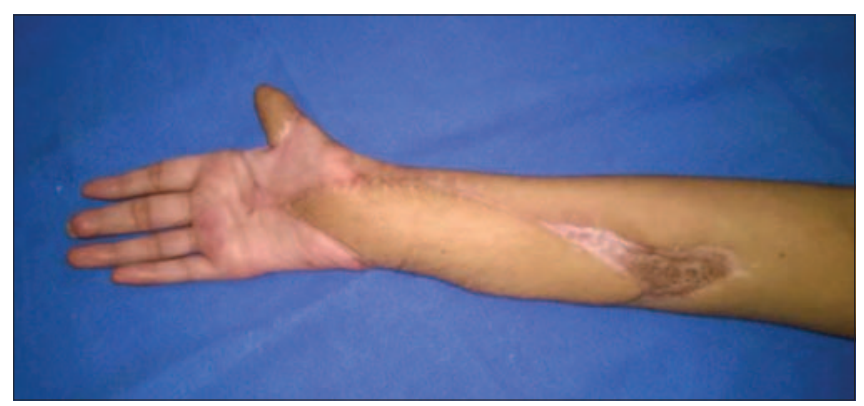

Figure 4: Salvaged limb

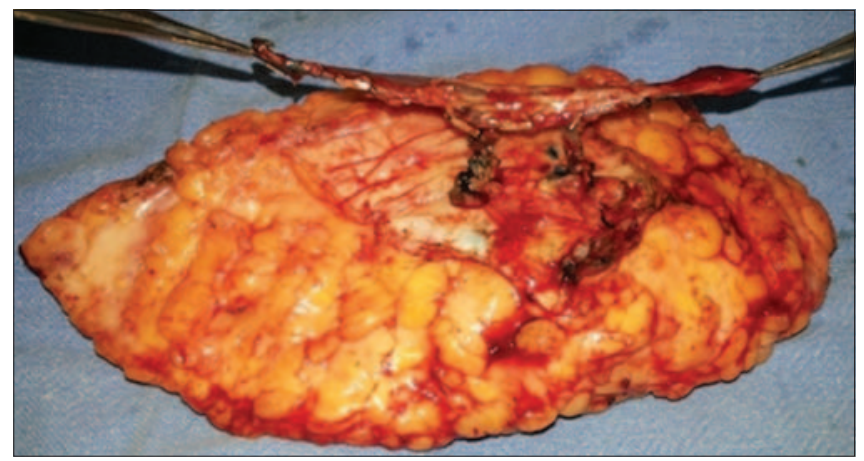

Figure 6: Harvested flow through flap

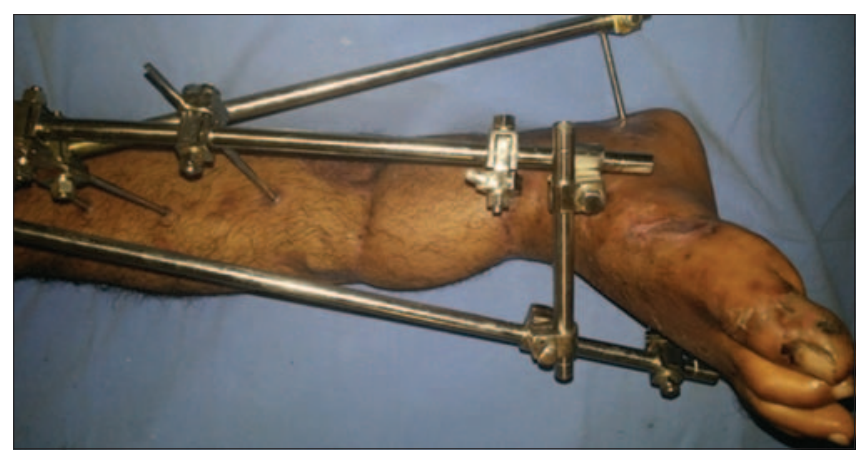

Figure 8: Salvaged foot and coverage of leg

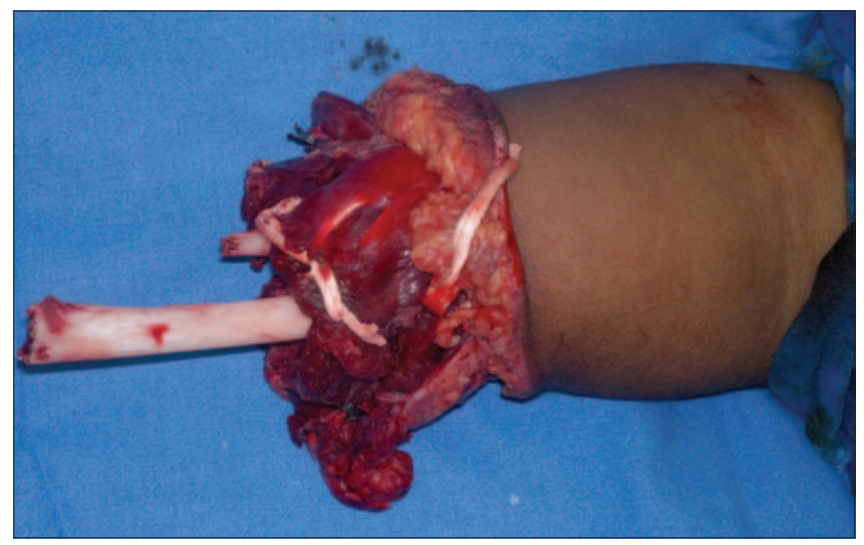

Figure 10: Proximal stump

On debridement, it was found that the radial vessels were thrombosed for $10 \mathrm{~cm}$ segment and hence a flow

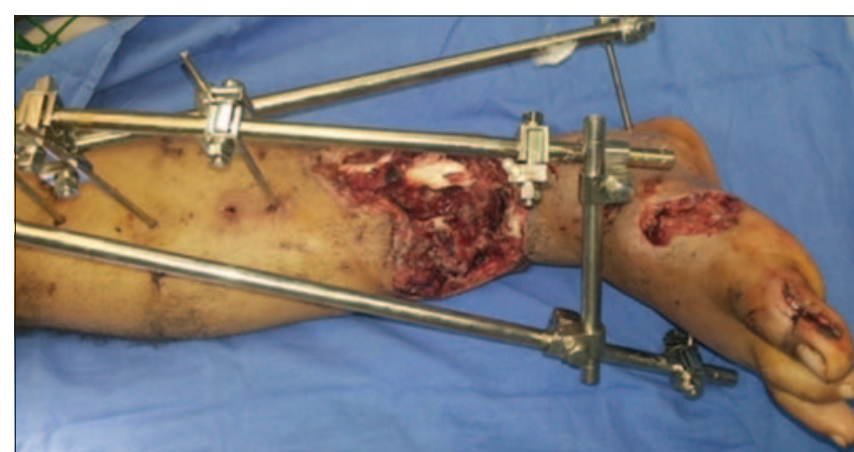

Figure 5: Soft tissue defect of leg with ischemia of foot

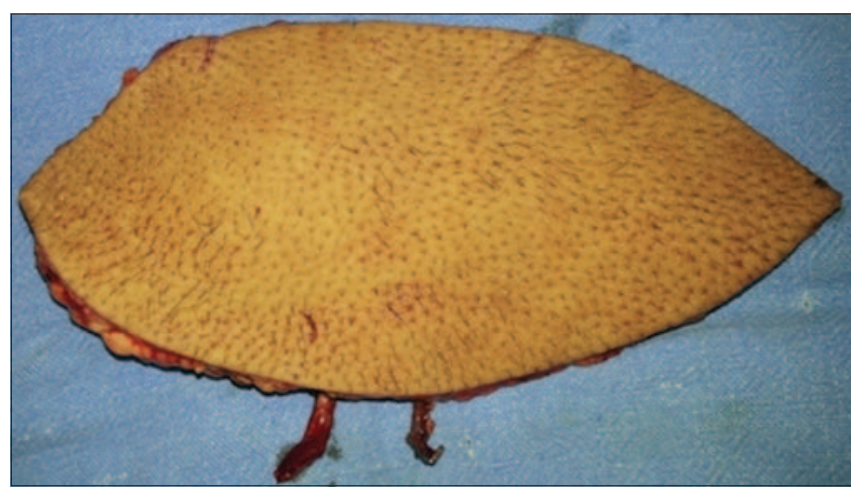

Figure 7: Flap cutaneous side

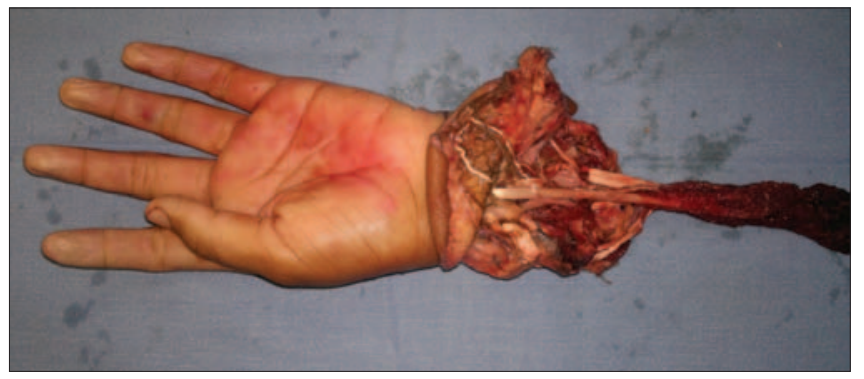

Figure 9: Amputation at distal forearm

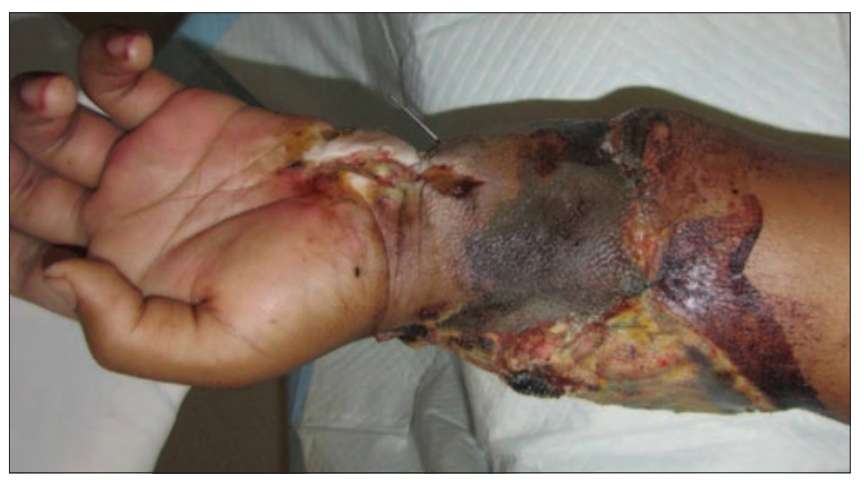

Figure 11: Necrosis of forearm skin and ischemic hand

through ALT flap was harvested and anastomosed with radial vessels [Figure 12]. The post-operation recovery was uneventful [Figures 13 and 14]. 
A 35-year-old patient presented $14 \mathrm{~h}$ after a crush injury to the distal right forearm with doubtful vascularity of hand [Figure 15]. He sustained fractures to both bones of the forearm which was managed with external fixator in a previous hospital. There was thrombosis of both the ulnar and radial vessels [Figure 16]. He was taken up for emergency ALT flow through flap [Figure 17]. Anastomosis was done with ulnar vessels. The flap survived, but the hand developed progressive thrombosis and had to be amputated [Figure 18].

\section{DISCUSSION}

A soft tissue defect with exposed vessels, nerves, bone or tendons can lead to severe morbidity and complications such as osteomyelitis. When revascularisation is necessary at the same time, a venous interposition

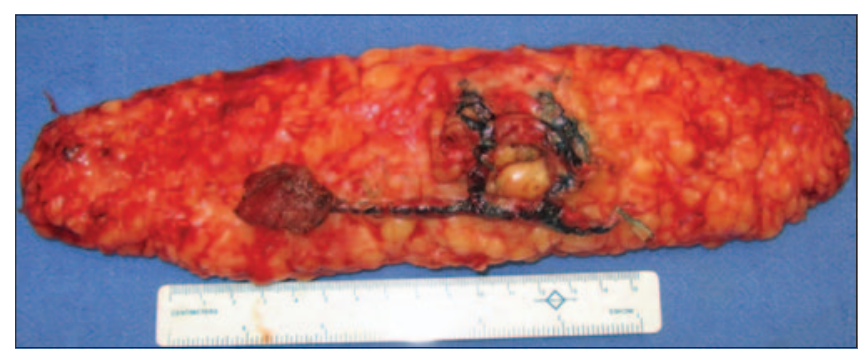

Figure 12: Harvested flow through flap

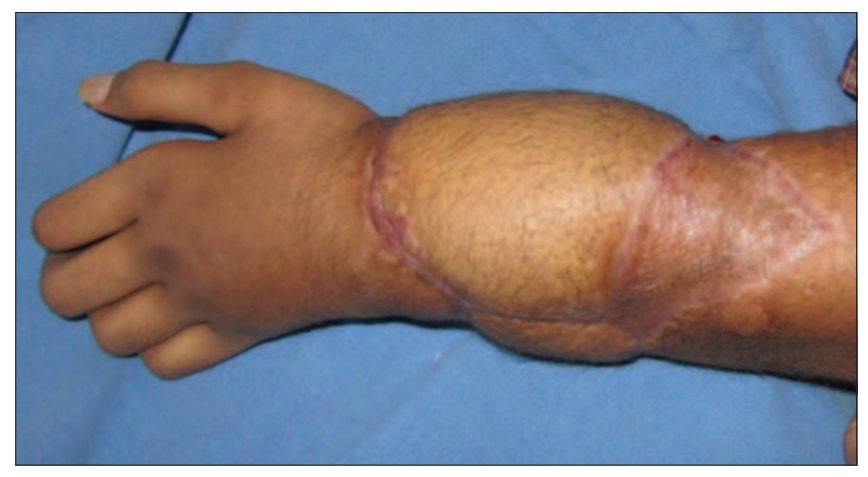

Figure 14: Salvaged hand

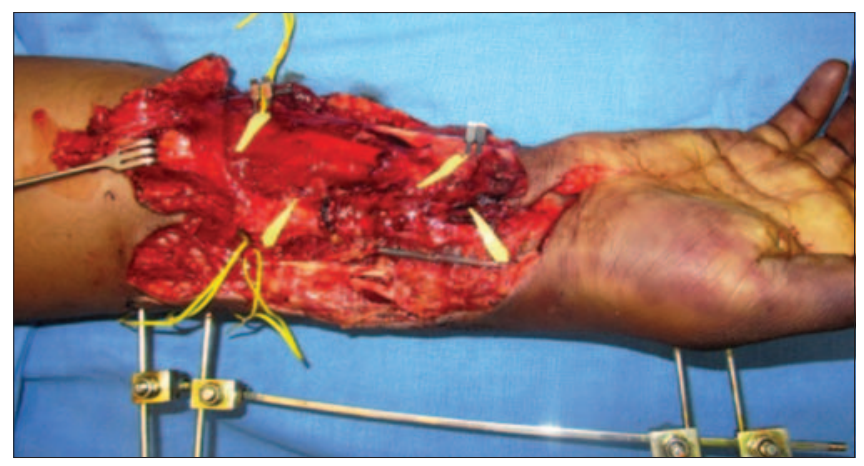

Figure 16: Soft tissue defect with thrombosed vessels graft in combination with a fasciocutaneous or musculocutaneous flap big enough to cover the defect can be used. An alternative one-stage solution is a flow-through flap. The first flaps thought useful as flow-through flaps were the antecubital forearm flap and the distal radial forearm flap. ${ }^{[1,2]}$ Costa et al. presented some cases of revascularisation of a traumatised limb using a radial forearm flap. ${ }^{[8]}$ Tseng et al. described a case of revascularisation of a near-amputated foot by a radial forearm flap. ${ }^{[9]}$ Septocutaneous perforator flaps are deemed suitable as a flow-through flap, like the ulnar flap and the lateral and medial flap from

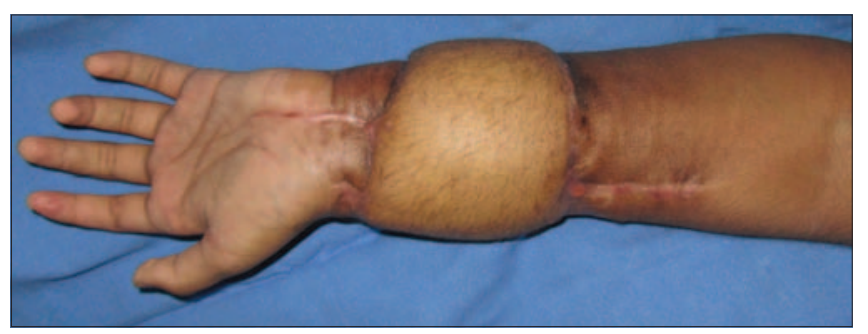

Figure 13: Post-operation recovery of hand

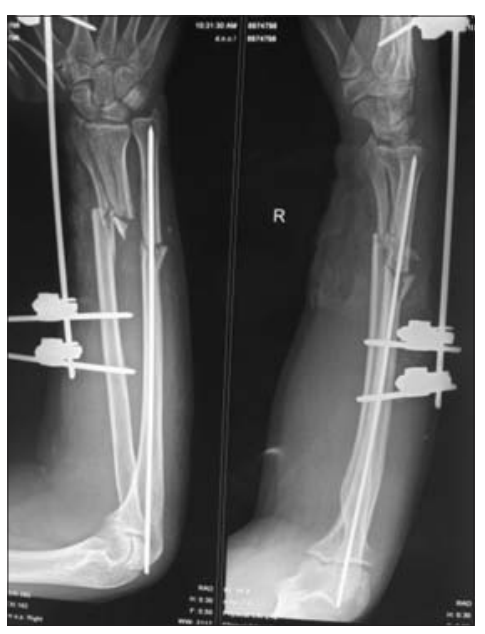

Figure 15: Fracture both bone forearm

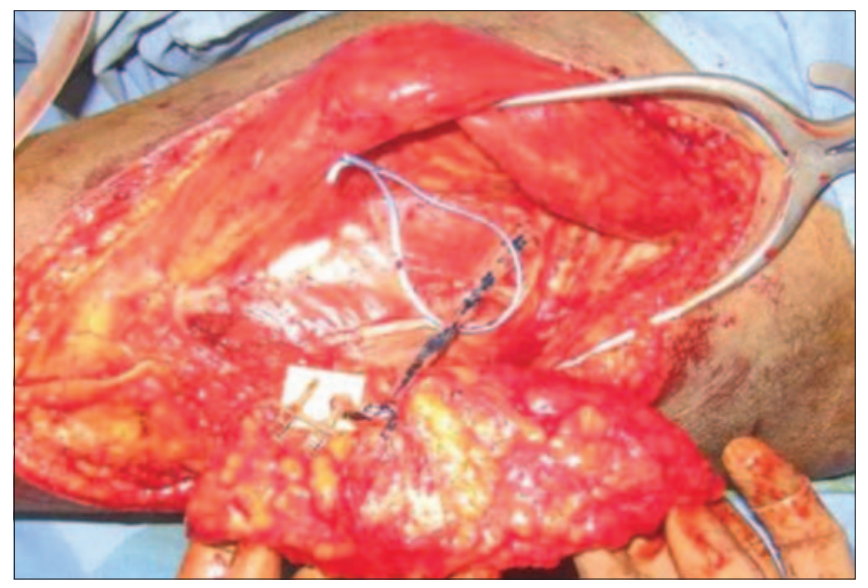

Figure 17: Harvesting of flap

Indian Journal of Plastic Surgery January-April 2016 Vol 49 Issue 1 


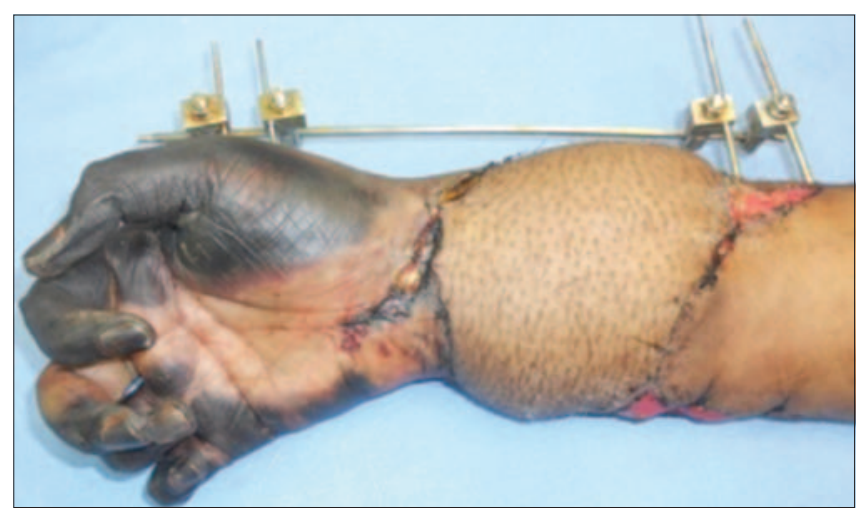

Figure 18: Progressive thrombosis of hand

the upper arm. The disadvantage of these flaps is the cosmetically poor outcome at the donor-site and the small flap size. ${ }^{[4]}$ Furthermore, the problem of coverage of the flexor tendons at the wrist can arise. ${ }^{[10]}$ Usually, a split-skin graft is required when using a forearm flap. Koshima et al. have used the ALT as a flow-through flap. ${ }^{[4]}$ In one of these cases, a flow-through flap was used to enhance the vascularity, 1.5 months after a traumatic defect of the foot. Ao et al. ${ }^{[3]}$ augmented the vascularity of the post-traumatic foot with the aid of an anterolateral or anteromedial thigh flap. In these cases, ischaemia can be prevented when the traumatised leg is a 'one-artery' leg. Song et al. first described the ALT flap as a fasciocutaneous flap with septocutaneous perforators. ${ }^{[5]}$ Song presents it as an easily dissected flap, with a large and long pedicle with the possibility for innervation. The skin has a good quality and can be raised in a large or irregular shape. The donor site is hidden and is, therefore, more acceptable to the patient..$^{[11,12]}$

He et al. ${ }^{[13]}$ have in their 2015 article reviewing 14 ALT flaps said that distal runoff vessel of the descending branch of the lateral circumflex femoral system could be used for many aspects of the ALT flap surgery, and we have in our series found the same to be highly relevant. In the cases presented there were those patients with ischaemia of the distal forearm and hand or lower third of the leg. Revascularisation was needed to preserve the extremities. For the soft tissue defect, a rather large skin island was needed. The flow-through ALT flap is an extremely versatile flap and assessed by us to be exceedingly suitable in these cases. The donor-site could be closed primarily in most of the patients. An additional advantage was provided by two teams working together and this minimised operative time and hence morbidity. The extremities were saved and vital structures could be covered in a one-stage procedure due to simultaneous successful revascularisation and coverage of the soft tissue defect with a flow-through ALT flap.

\section{CONCLUSION}

The ALT flow-through flap is an extremely versatile and useful flap that must be considered whenever there is a need to salvage an ischemic limb with soft tissue loss. In a single step procedure both the revascularisation and closure of the soft tissue defect can be achieved avoiding the need for interpositional vein graft. This also minimises morbidity and hastens recovery.

\section{Financial support and sponsorship Nil.}

\section{Conflicts of interest}

There are no conflicts of interest.

\section{REFERENCES}

1. Soutar DS, Scheker LR, Tanner NS, McGregor IA. The radial forearm flap: A versatile method for intra-oral reconstruction. $\mathrm{Br} \mathrm{J}$ Plast Surg 1983;36:1-8.

2. Lamberty BG, Cormack GC. The antecubital fascio-cutaneous flap. Br J Plast Surg 1983;36:428-33.

3. Ao M, Nagase $Y$, Mae $O$, Namba Y. Reconstruction of posttraumatic defects of the foot by flow-through anterolateral or anteromedial thigh flaps with preservation of posterior tibial vessels. Ann Plast Surg 1997;38:598-603.

4. Koshima I, Kawada S, Etoh H, Kawamura S, Moriguchi T, Sonoh H. Flow-through anterior thigh flaps for one-stage reconstruction of soft-tissue defects and revascularization of ischemic extremities. Plast Reconstr Surg 1995;95:252-60.

5. Song YG, Chen GZ, Song YL. The free thigh flap: A new free flap concept based on the septocutaneous artery. Br J Plast Surg 1984;37:149-59.

6. Kimata Y, Uchiyama K, Ebihara S, Sakuraba M, lida H, Nakatsuka T, etal.Anterolateral thigh flap donor-site complications and morbidity. Plast Reconstr Surg 2000;106:584-9.

7. Kuo YR, Jeng SF, Kuo MH, Huang MN, Liu YT, Chiang YC, et al. Free anterolateral thigh flap for extremity reconstruction: Clinical experience and functional assessment of donor site. Plast Reconstr Surg 2001;107:1766-71.

8. Costa H, Guimarães I, Cardoso A, Malta A, Amarante J, Guimarães $F$. One-staged coverage and revascularisation of traumatised limbs by a flow-through radial mid-forearm free flap. Br J Plast Surg 1991;44:533-7.

9. Tseng WS, Chen HC, Hung J, Tasi TR, Chen HH, Wei FC. "Flow-through" type free flap for revascularization and simultaneous coverage of a nearly complete amputation of the foot: Case report and literature review. J Trauma 
2000;48:773-6.

10. Deutman HC, Hartman EH, Marres HA. A buried reversed radial forearm flap in pharyngeal reconstruction: Refinements and monitoring. Eur J Plast Surg 2000;23:204-7.

11. Lee JW, Yu JC, Shieh SJ, Liu C, Pai JJ. Reconstruction of the Achilles tendon and overlying soft tissue using antero-lateral thigh free flap. Br J Plast Surg 2000;53:574-7.
12. Luo S, Raffoul W, Luo J, Luo L, Gao J, Chen L, et al. Anterolateral thigh flap: A review of 168 cases. Microsurgery 1999;19:232-8.

13. He XQ, Zhu YL, Wang Y, Mei LB, Jin T, Xu YQ. The role of the distal runoff vessel of the descending branch of the lateral circumflex femoral system in anterolateral thigh flap surgery: A case series and literature review. Ann Plast Surg 2015 [epub ahead of print].

\section{Staying in touch with the journal}

1) Table of Contents (TOC) email alert

Receive an email alert containing the TOC when a new complete issue of the journal is made available online. To register for TOC alerts go to www.ijps.org/signup.asp.

\section{2) RSS feeds}

Really Simple Syndication (RSS) helps you to get alerts on new publication right on your desktop without going to the journal's website. You need a software (e.g. RSSReader, Feed Demon, FeedReader, My Yahoo!, NewsGator and NewzCrawler) to get advantage of this tool. RSS feeds can also be read through FireFox or Microsoft Outlook 2007. Once any of these small (and mostly free) software is installed, add www.ijps.org/rssfeed.asp as one of the feeds. 